\title{
The Pedagogical Evaluation of Q: Skills for Success Textbooks as Perceived by EFL Instructors at Taibah University
}

\author{
Dr. Mohammad Abd Alhafeez Ali Ta'amneh (Corresponding author) \\ Associate Professor of English Language Curriculum and Instruction \\ Taibah University
}

E-mail: Taamnehmohammad@yahoo.com

Received: May 1, 2019 Accepted: May 20, 2019 Published: June 3, 2019

doi:10.5296/ijld.v9i2.14731 URL: https://doi.org/10.5296/ijld.v9i2.14731

\begin{abstract}
This study evaluated Q: Skills for Success textbooks for first year students from EFL instructors' perspectives at Taibah University to find practical implications for stressing major strengths and avoiding weak points in these textbooks and consequently developing students' growth in EFL learning. The participants consisted of fifty EFL instructors teach these textbooks at Taibah University. They were asked to answer the questionnaire which was developed by the researcher to discover their beliefs about adopting the new textbooks. The question of the study was about instructors' beliefs regarding pedagogical value of Q: Skills for Success in terms of objectives, contents, methods, and evaluation. Results revealed that these textbooks helped students in improving their proficiency in English, developing self-confidence and improving their overall education. English instructors, according to their responses, agreed on the suitability of Q: Skills for Success textbooks in terms of objectives, contents, methods and techniques and ways of evaluation. However, the findings revealed some negative points concentrated on the appropriateness of content and pictures to the local culture of the students in addition to the absence of instructors' participation in the selection of objectives. In light of the findings, the researcher suggested other researchers to conduct similar studies in other regions to find out if there are cultural differences concerning teaching Q: Skills for Success textbooks.
\end{abstract}

Keywords: Cultural differences, instructors' beliefs, pedagogy, appropriateness, suitability, English language learning, textbook development 


\section{Introduction}

English language is an essential tool for communication between countries. It is viewed as an essential instrument for educational and technological development. It is also considered as a means of gaining insight into other cultures and patterns of thinking. A good educational system should be provided with modern textbooks and guidelines for current teaching methods (Ta'amneh, 2014). Textbooks play a significant role in the process of teaching and learning English. They present helpful ready-made material to instructors and learners. Hutchinson and Torres (1994) consider textbooks as an instrument for supporting instructors and as a tool of modifications. Instructors believe that textbooks are very useful aids that present practical and valuable material that learners need to guide them through learning. They provide teachers and students with a structure of teaching and learning, practical and methodological support and opportunities for revision and preparation (McGrath, 2002). Textbooks are an efficient and useful resource for knowledge, ideas and activities, a reference source for learners, a curriculum where they reflected programmed learning objectives and supported for inexperienced instructors to increase confidence (Cunnigsworth, 1995).

In recent years, Taibah University has adopted new English textbooks for the first year students called Q: Skills for Success to improve the quality of English learning. The new English textbooks aim to develop English learning, enlarge students 'skills and enhance their knowledge at different levels. Q: Skills for Success is a six-level- paired skills series, Reading, Writing, Listening and Speaking, that helps students to think critically and succeed academically. It has clearly stated unit objectives that encourage learners to achieve their goals. The online content allows teachers to apply blended learning into the classroom. Every book consists of the following parts: Student Book with iQ Online, Student e-book with iQ Online, Split Student Book A with iQ Online, Split Student Book B with iQ Online, iTools Online, iTools USB, iQ Online student access card and iQ Online teacher access card. The Reading and Writing book has pictures, vocabulary practice, guided writing practice, learning activities, copying exercises, and sentence writing practice. The Listening and Speaking book contains speaking activities, listening tasks, and grammatical practices (Bixby \& McVeigh, 2011).

Evaluation refers to the process of delineating, obtaining and providing on the merit of the goals, designs, implementation and outcomes of educational activities. It should help to improve an educational product during the process of its development and/or demonstrate the merit of the final product when its development is completed, (Nevo, 1977, 127). It may help decision maker to make successful and valuable decisions depending on the results of evaluations. It is considered to be a part of the teaching and learning process that gives the continuous feedback of data to keep the system in adjustment, (Banks \& Ambrose, 1977. 489-490). It is also an integral part of educational programs which is used for providing feedback for both instructors and students in the process of teaching and learning. Furthermore, evaluation is a process of providing important information on the merit of goals, designs, instructions, contents and the effectiveness of educational activities for students, teachers, textbook authors and other decision makers. The evaluation process is very important to show decision makers whether something is of good or bad quality and whether a given goal has been realized or not, (Nevo, 1977, 127). Some researchers consider it as one of the basic 
components of any curriculum. Ta'amneh (2015) considers evaluation depending on teachers' perspectives as a very important procedure in developing the processes of teaching and learning. Rea-Dickins and Germaine (1994) states that "evaluation is an intrinsic part of teaching and learning" (p.4). Cunningsworth (1995) and Ellis (1997) state that evaluating textbooks helps instructors go beyond generalized assessments and it helps them to gain practical, precise, organized and appropriate insights into the overall nature of material found in textbooks.

Textbook evaluation provides practical information for teachers and plans learning for learners. Grant (1987) states that the best textbook must match the learners' abilities and interests, and suit the instructors' interests. Evaluation studies are important and necessary because they provide a basis for decision making and policy formation. In addition, they assess students' achievement, evaluate curricula, accredit schools, monitor expenditure of pupils' funds and improve educational materials and programs (Worthen \& Sanders, 1987:5).

In spite of the different explanations of evaluation, most researchers concentrated on its importance in improving textbooks by providing relevant information that should be described and analyzed for better decisions about educational programs. Since Q: Skills for Success textbooks are new, it is necessary to evaluate these textbooks in order to discover the weak and strong points of its objectives, contents, methods and techniques and ways of evaluation.

\subsection{Significance of the Study}

Taibah University is trying to improve its educational system. To achieve this general aim, it has adopted the new textbook series (Q: Skills for Success) for first year students. In this regard, it is worth asking if these textbooks meet the aims and goals stated by Taibah University or not, and if they satisfy the learners' needs. The significance of this study derives from the fact that, as far as the researcher knows, there is not any study investigated these textbooks. Thus, English curricula planners may find practical implications in this study for stressing major strengths and avoiding weak points in these textbooks and consequently developing students' growth in EFL learning.

\subsection{Definitions of terms}

\subsubsection{EFL Instructors}

They are the instructors who teach Q: Skills for Success textbooks at Taibah University.

\subsubsection{Q: Skills for Success Textbooks}

They refer to the English textbooks for the first year students at Taibah University.

\subsubsection{Pedagogical Evaluation}

It is the method of giving significant information about the effectiveness of educational activities for learners, instructors, textbook authors.

\subsubsection{Instructors' Perspectives}

They refer to the beliefs about Q: Skills for Success textbooks for the first year students at 
Taibah University depending on the teaching experiences. In this study, the instructors' perspectives were determined using instructors' questionnaire.

\subsection{Statement of the Problem}

Evaluation the Q: Skills for Success textbooks may bring a very deep understanding and important information to the English learning context. This process may determine the strengths and weaknesses of these textbooks. To the researcher's best knowledge, there is no attempt to evaluate these textbooks and, thus, an evaluation of its pedagogical value from EFL instructors' perspective may provide deeper insights into its pedagogical effectiveness which may inform its utilization in the language classroom. More specifically, this study attempted to find out EFL instructors' responses toward these textbooks in terms of objectives, contents, method and techniques and ways of evaluation and the reliability of the newly-introduced textbooks by identifying the extent to which these textbooks match the needs and of EFL learners. It answered the following question:

1. What are the EFL instructors' beliefs about the pedagogical value of the new textbooks (Q: Skills for Success) in terms of its objectives, contents, methods and ways of evaluation for the first year students at Taibah University?

\subsection{Limitations of the Study}

This study was conducted at Taibah University during the first semester of the academic year 201611017. The results of this study was restricted to EFL Instructors' perspectives who teach Q: Skills for Success textbooks at Taibah University and to the Q: Skills for Success textbooks for the first year students. In addition, the study used closed-ended questions questionnaire and this resulted in limitations on instructors' responses. However, interviews EFL instructors and ask them open ended questions could have added more depth to the research.

\section{Review of Related Literature}

Ta'amneh (2005) investigated Action Pack Textbooks for the first six grades in Jordan from supervisors' and teachers' perspectives. The results revealed that the respondents were agreed on the suitability of these textbooks concerning content, methods and techniques, objectives and ways of evaluation. There were no significant effects in their responses according to position, gender, and experience, but there was a significant difference in methods and techniques related to directorates of education.

Al-Barakat, Bataineh, Al-Karasneh \& Bataineh (2006) evaluated the pedagogical effectiveness of the Action Pack Textbook Series for the first four primary classes in Jordanian public schools from teachers' responses. The results revealed that Action Pack Textbook Series was adaptable to both teachers' and pupils' needs, provided a broad range of resources that can be selectively integrated into the curriculum. It had interesting, effective and flexible instructional materials. The findings also revealed that these textbooks had a well written and compelling content for promoting learning.

Moirano (2012) conducted a study to discover teachers' attitudes towards culture in the EFL classroom in three different institutions in Argentina. Teachers who participated in this study 


\section{Macrothink}

were interviewed through a semi-structured questionnaire. They used three different EFL textbooks which were World English 3, Laser B1+, and Upstream B2+. The findings revealed that textbooks used in La Plata, Argentina tended to deal with and to avoid the equal topics and that they were not identity enhancers for local learners. It also showed that teachers did not notice this problem easily and did a little effort to solve it.

Ahmad and Shah (2014) explored the relationship between studying English textbooks (New Headway Plus Special Edition) and the probable changes in cultural attitudes of Saudi EFL learners to address the relationship between English proficiency and the cultural attitudes of the learners. The findings revealed that these textbooks failed to promote the element of intercultural understanding because of nonexistent Islamic or Saudi depiction. Good English proficiency learners achieved better in the linguistic aspects of the language and absorbed its cultural elements compared with the less proficient learners. The researchers suggested that the curriculum designers had to take into consideration the important role of learners' cultural aspects while designing and writing EFL textbooks.

Al-Nafisah and Al-Shorman (2014) investigated twenty-seven EFL instructors' perspectives about Interactions Series used in Saudi universities. Results discovered that the respondents, who were male instructors at King Saud University, found the Interactions Series as appropriate and effective for teaching English to Saudi university students.

Abu Naba'h, Abu Samak, and Massoud (2016) explored the EFL teachers perceptions about "Liftoff for Saudi Arabia" Series. The findings revealed that the participants agreed on the suitability of this series. The researches gave suggestions for improving the series such as reducing the number of units, using appropriate Islamic vocabulary in texts, providing classrooms with appropriate technological tools.

Alshehri (2016) evaluated Cutting Edge textbook according to the six areas: skills, activities, layout and design, language type, subject and content, and practical considerations. The results revealed that the instructors were satisfied with a majority of the textbook's features. They were satisfied with the textbook's layout and design, subject and content, skills component, activities and language type. Conversely, instructors' opinions about the textbook's practical considerations were imprecise and unclear.

Aldera (2017) analyzed the impact of foreign cultures on EFL students in Saudi universities. Results showed that the textbooks ignored the Saudi culture and included mainly foreign cultures. It demonstrated that the second language learners disagree with the control of foreign culture in their textbooks. Analysis showed a very positive attitude towards strange cultures that do not contradict with their values.

Al Harbil (2017) evaluated EFL textbook for secondary stage in Saudi Public schools. The study covered five items: layout and design, the objectives of the textbook, teaching methods and activities, language skills, and evaluation. Results revealed that EFL textbook needs improvements to make the process of learning and teaching English more effective. The objectives were not clear according to the teachers' comments. In addition, The content was not helpful in applying teaching theories and did not have helpful procedures to evaluate 


\section{Macrothink}

learners effectively.

\section{Methodology}

The researcher discusses the procedures followed in this study. He describes the population and sample, instrument, and validity and reliability of the instrument.

\subsection{Population and Sample of the Study}

The population of the study consisted of all EFL instructors teaching Q: Skills for Success at Taibah University. The sample, who responded to the questionnaire, consisted of fifty (50) instructors teaching these textbooks at Taibah University.

\subsection{Instrument of the Study}

The researcher developed a questionnaire for the instructors. It was developed to discover their beliefs about adopting the new textbook series for first year students at Taibah University and the pedagogical value of this new series.

\subsection{Validity and Reliability of the Instrument}

Ten specialists were asked to examine the questionnaire and provide their suggestions. The researcher chose ten EFL instructors, responded to the questionnaire twice with a two-week interval between them, from the population but outside of the study. The reliability coefficient was computed using Cronbach Alpha. The calculated value was .91 which is high enough to conduct the study.

\section{Findings of the Study}

The question of the study was about EFL instructors' beliefs about the pedagogical value of Q: Skills for Success for first year students at Taibah University in terms of objectives, contents, methods, and evaluation. The following tables show the results. 
Table 1. Descriptive Statistics of Content Items

\begin{tabular}{|c|c|c|c|c|c|c|c|c|}
\hline & $\mathrm{N}$ & Range & Min & Max & Sum & Mean & & $\begin{array}{l}\text { Std. } \\
\text { Deviation }\end{array}$ \\
\hline & Statistic & Statistic & Statistic & Statistic & Statistic & Statistic & $\begin{array}{l}\text { Std. } \\
\text { Error }\end{array}$ & Statistic \\
\hline $\begin{array}{l}\text { The lessons and units are } \\
\text { organized logically. }\end{array}$ & 50 & 1 & 4 & 5 & 235 & 4.70 & .065 & .463 \\
\hline $\begin{array}{l}\text { The length of lessons holds } \\
\text { learners interests. }\end{array}$ & 50 & 3 & 2 & 5 & 219 & 4.38 & .099 & .697 \\
\hline $\begin{array}{l}\text { The arrangement of grammar } \\
\text { holds students' interest. }\end{array}$ & 50 & 3 & 2 & 5 & 208 & 4.16 & .135 & .955 \\
\hline $\begin{array}{l}\text { The topics of units vary to enrich } \\
\text { students' thinking. }\end{array}$ & 50 & 2 & 3 & 5 & 222 & 4.44 & .082 & .577 \\
\hline The content is presented clearly. & 50 & 2 & 3 & 5 & 220 & 4.40 & .095 & 670 \\
\hline $\begin{array}{l}\text { The content is relevant to the } \\
\text { learner's culture. }\end{array}$ & 50 & 4 & 1 & 5 & 87 & 1.74 & .127 & .899 \\
\hline $\begin{array}{l}\text { The design of the content is } \\
\text { appropriate. }\end{array}$ & 50 & 3 & 2 & 5 & 208 & 4.16 & .152 & 1.076 \\
\hline $\begin{array}{l}\text { The size of the textbook is } \\
\text { suitable. }\end{array}$ & 50 & 4 & 1 & 5 & 207 & 4.14 & .183 & 1.294 \\
\hline The content is valid. & 50 & 2 & 3 & 5 & 224 & 4.48 & .091 & .646 \\
\hline The content is accurate. & 50 & 2 & 3 & 5 & 218 & 4.36 & .080 & .563 \\
\hline
\end{tabular}

The findings concerning the content of Q: Skills for Success were suitable and appropriate. As shown in Table 1, instructors thought that lessons and units were organized logically. They agreed that the length of teaching lessons and the arrangement of grammar holed learners` interests. Besides, they believed that the topics of each unit in these textbooks were different and presented clearly, appropriately and accurately to enrich students' thinking. On the other hand, instructors' responses were not in agreement with the appropriateness of content according to the learner's culture. The mean for the item that referred to the appropriateness of content to the students' culture was (1.74). This result could be described as an indicator that EFL instructors felt that the content of these textbooks should be modified to be more relevant to the students' culture. This result agreed with the findings of Ahmad and Shah (2014) who found that English textbooks (New Headway Plus Special Edition) failed to promote the element of intercultural understanding because of nonexistent Islamic or Saudi depiction. Accordingly, they suggested that the curriculum designers had to be aware of the important role of learners' cultural aspects while designing and writing EFL textbooks. 


\section{Macrothink}

Table 2. Descriptive Statistics of Methods, Techniques, and Pictures Items

\begin{tabular}{|c|c|c|c|c|c|c|c|c|}
\hline & \multirow[b]{2}{*}{$\mathrm{N}$} & \multirow[b]{2}{*}{ Range } & \multirow[b]{2}{*}{ Min } & \multirow[b]{2}{*}{ Max } & \multirow[b]{2}{*}{ Sum } & \multicolumn{2}{|l|}{ Mean } & \multirow{2}{*}{$\begin{array}{l}\text { Std. } \\
\text { Deviation }\end{array}$} \\
\hline & & & & & & Statistic & $\begin{array}{l}\text { Std. } \\
\text { Error }\end{array}$ & \\
\hline $\begin{array}{l}\text { Methods are suitable in achieving the } \\
\text { objectives of the textbooks. }\end{array}$ & 50 & 2 & 3 & 5 & 217 & 4.34 & .079 & .557 \\
\hline $\begin{array}{l}\text { I feel that the methods suggested in the } \\
\text { curriculum vary. }\end{array}$ & 50 & 2 & 3 & 5 & 211 & 4.22 & .096 & 679 \\
\hline $\begin{array}{l}\text { I believe I can state methods that } \\
\text { reinforce learners' understanding. }\end{array}$ & 50 & 3 & 2 & 5 & 213 & 4.26 & .102 & .723 \\
\hline $\begin{array}{l}\text { I can state methods that enrich the } \\
\text { learner's thinking. }\end{array}$ & 50 & 2 & 3 & 5 & 215 & 4.30 & .077 & .544 \\
\hline $\begin{array}{l}\text { I suppose that the utterance of listening } \\
\text { tracks is suitable. }\end{array}$ & 50 & 2 & 3 & 5 & 224 & 4.48 & .091 & .646 \\
\hline $\begin{array}{l}\text { I notice that the length of utterance is } \\
\text { appropriate. }\end{array}$ & 50 & 1 & 4 & 5 & 232 & 4.64 & .069 & .485 \\
\hline $\begin{array}{l}\text { I think that pictures found in the } \\
\text { textbooks are appropriate. }\end{array}$ & 50 & 4 & 1 & 5 & 218 & 4.36 & .151 & 1.064 \\
\hline I believe that pictures are attractive. & 50 & 2 & 3 & 5 & 212 & 4.24 & .120 & .847 \\
\hline $\begin{array}{l}\text { I think that the pictures introduced in the } \\
\text { lessons are relevant to the learner's } \\
\text { culture. }\end{array}$ & 50 & 4 & 1 & 5 & 107 & 2.14 & .204 & 1.443 \\
\hline $\begin{array}{l}\text { I see that the pictures are relevant to the } \\
\text { course. }\end{array}$ & 50 & 3 & 2 & 5 & 209 & 4.18 & .117 & .825 \\
\hline
\end{tabular}

As shown in Table (2), instructors' perspectives about the methods used in the newly adopted textbooks (Q Skills for Success) were acceptable. They agreed that methods were suitable in achieving the objectives of the textbooks. Furthermore, they believed that methods found in the textbooks were varied according to students' levels, reinforced students' understanding and enriched their thinking. There were no comments concerning the listening tracks; they considered them as suitable and appropriate. Although pictures were described as attractive, appropriate and relevant to the course, instructors felt that they were not fully relevant to the students' culture. They thought that they ought to be changed or modified to be more acceptable in the local culture. Some pictures, depending on the instructors' opinions, should be revised and modified to suit the local culture of the students. This result of findings supported what had obtained by Ahmad and Shah (2014) and Aldera (2017) who found that the textbooks ignored the Saudi culture and included mainly foreign cultures. 


\section{Macrothink}

Table 3. Descriptive Statistics of Objectives

\begin{tabular}{|c|c|c|c|c|c|c|c|c|}
\hline & \multirow[b]{2}{*}{$\mathrm{N}$} & \multirow[b]{2}{*}{ Range } & \multirow[b]{2}{*}{ Min } & \multirow[b]{2}{*}{ Max } & \multirow[b]{2}{*}{ Sum } & \multicolumn{2}{|l|}{ Mean } & \multirow{2}{*}{$\begin{array}{l}\text { Std. } \\
\text { Deviation }\end{array}$} \\
\hline & & & & & & Statistic & $\begin{array}{l}\text { Std. } \\
\text { Error }\end{array}$ & \\
\hline $\begin{array}{l}\text { I think that the statements of general and } \\
\text { specific objectives are appropriate. }\end{array}$ & 50 & 2 & 3 & 5 & 218 & 4.36 & .089 & .631 \\
\hline $\begin{array}{l}\text { The objectives are graded according to } \\
\text { the learners' levels. }\end{array}$ & 50 & 3 & 2 & 5 & 209 & 4.18 & .106 & .748 \\
\hline $\begin{array}{l}\text { The objectives are graded according to } \\
\text { their importance. }\end{array}$ & 50 & 4 & 1 & 5 & 186 & 3.72 & .159 & 1.126 \\
\hline $\begin{array}{l}\text { The objectives are clear enough for } \\
\text { instructors to achieve. }\end{array}$ & 50 & 2 & 3 & 5 & 221 & 4.42 & .081 & .575 \\
\hline $\begin{array}{l}\text { Instructors participate in the selection of } \\
\text { objectives. }\end{array}$ & 50 & 4 & 1 & 5 & 152 & 3.04 & .218 & 1.538 \\
\hline The objectives are possible to achieve. & 50 & 3 & 2 & 5 & 222 & 4.44 & .115 & .812 \\
\hline $\begin{array}{l}\text { The objectives are related to the learner's } \\
\text { needs. }\end{array}$ & 50 & 3 & 2 & 5 & 213 & 4.26 & .117 & .828 \\
\hline $\begin{array}{l}\text { The objectives are appropriate for the } \\
\text { learner's level. }\end{array}$ & 50 & 4 & 1 & 5 & 189 & 3.78 & .135 & .954 \\
\hline $\begin{array}{l}\text { I observe that the objectives are related to } \\
\text { the learners` future life. }\end{array}$ & 50 & 4 & 1 & 5 & 209 & 4.18 & .142 & 1.004 \\
\hline The objectives motivate learners to think. & 50 & 4 & 1 & 5 & 215 & 4.30 & .141 & .995 \\
\hline
\end{tabular}

Objectives, according to Table 3, were considered to be appropriate and applicable. Responses were positive in general. Instructors believed that the objectives of Q: Skills for Success were appropriate, graded according to learners' levels, clear enough and possible to be achieved. They also thought that those objectives were related to the learner's needs, levels and learners' future life. In spite of appropriateness of objectives as shown in the above table, EFL instructors felt that there did participate in the selection of appropriate and applicable general and specific objectives that went with their students' levels as shown in figure 3 . They felt that participating in the selection of objectives may give them self-confidence to teach these textbooks effectively and purposefully. The absence of instructors' contributions might lead them to the fact that the new textbooks did not differ from other textbooks which ignore teachers' experience while designing and writing English textbooks by practitioners. 
Table 4. Descriptive Statistics of Evaluation Items

\begin{tabular}{|c|c|c|c|c|c|c|c|c|}
\hline & \multirow[b]{2}{*}{$\mathrm{N}$} & \multirow[b]{2}{*}{ Range } & \multirow[b]{2}{*}{ Min } & \multirow[b]{2}{*}{ Max } & \multirow[b]{2}{*}{ Sum } & \multicolumn{2}{|l|}{ Mean } & \multirow[b]{2}{*}{$\begin{array}{l}\text { Std. } \\
\text { Deviation }\end{array}$} \\
\hline & & & & & & Statistic & $\begin{array}{l}\text { Std. } \\
\text { Error }\end{array}$ & \\
\hline $\begin{array}{l}\text { Exercises are clear enough } \\
\text { for the learners to deal with. }\end{array}$ & 50 & 1 & 4 & 5 & 231 & 4.62 & .069 & .490 \\
\hline $\begin{array}{l}\text { Exercises are relevant to the } \\
\text { learners' need. }\end{array}$ & 50 & 2 & 3 & 5 & 223 & 4.46 & .091 & .646 \\
\hline $\begin{array}{l}\text { Exercises vary to enrich } \\
\text { learners' thinking. }\end{array}$ & 50 & 2 & 3 & 5 & 221 & 4.42 & .081 & .575 \\
\hline $\begin{array}{l}\text { Exercises attract the } \\
\text { learners' attention. }\end{array}$ & 50 & 3 & 2 & 5 & 208 & 4.16 & .096 & .681 \\
\hline $\begin{array}{l}\text { The organization of the } \\
\text { exercises is appropriate. }\end{array}$ & 50 & 3 & 2 & 5 & 215 & 4.30 & .096 & .678 \\
\hline $\begin{array}{l}\text { Exercises are graded } \\
\text { according to their difficulty. }\end{array}$ & 50 & 3 & 2 & 5 & 209 & 4.18 & .117 & .825 \\
\hline $\begin{array}{l}\text { Exercises are related to the } \\
\text { student's book. }\end{array}$ & 50 & 3 & 2 & 5 & 227 & 4.54 & .108 & .762 \\
\hline Exercises are attractive. & 50 & 2 & 3 & 5 & 217 & 4.34 & .079 & .557 \\
\hline $\begin{array}{l}\text { Exercises are related to the } \\
\text { general and specific } \\
\text { objectives. }\end{array}$ & 50 & 1 & 4 & 5 & 234 & 4.68 & .067 & .471 \\
\hline $\begin{array}{l}\text { Exercises are related to the } \\
\text { learners` environment. }\end{array}$ & 50 & 4 & 1 & 5 & 202 & 4.04 & .164 & 1.160 \\
\hline
\end{tabular}

The information shown in Table 4 showed that EFL responses about assessment and evaluation found in the textbooks were suitable and satisfied. The average mean was 4.37. Instructors looked for exercises found in the textbooks as clear enough for the learners to deal with, relevant to the learners' need and varied to enrich learners` thinking. They thought that they are arranged logically and appropriately. Furthermore, they were, according to instructors' responses, related to the covered material and to the objectives of the textbooks.

\section{Discussion of Findings}

The lack of the appropriateness of content and pictures to the local culture of the students and improper representation of Saudi culture in the Q: skills for success textbooks is one of the factors that make the process of learning and teaching boring and uninteresting. As a result, students may think that ignoring their own culture while learning English language may result in losing their identity. Therefore, the topics presented in the book are not motivating them to talk and participate inside and outside the classroom. Besides, English instructors may face some problems while teaching foreign values if they are opposed to the (Arab) Muslim values (Mohd-Ashraf, 2005). Therefore, if intercultural understanding has to be accomplished, the EFL instructors as well as the textbook authors may have the responsibility of present a reasonable share to various cultures and values around the world (Ahmad and Shah 2014). 


\section{Macrothink}

The absence of instructors' participation in the selection of objectives and exercises demotivate them and make the process of learning as well as the past experience that they had. They make them feel that there is no new role for EFL instructors in teaching these textbooks. The absence of instructors' contributions might lead them to the fact that the new textbooks do not differ from past textbooks which ignore instructors' knowledge and skills while designing the new textbooks.

In spite of some negative points mentioned in the previous discussion which were concentrated on the appropriateness of content and pictures to the local culture of the students in addition to the absence of instructors' participation in the selection of objectives, the findings found that Q: skills for success textbooks helped students in improving their proficiency in English, developing self-confidence and improving their overall education. Since these textbooks were newly adopted by Taibah University for first year students, instructors' knowledge and experience might be transferred to others in the field as well as to those who learned these textbooks. In brief, this study showed that EFL instructors agreed on the suitability of the newly adopted textbooks in terms of the four domains (objectives, contents, methods and techniques and ways of evaluation) which were used to discover the strengths and weaknesses of these textbooks.

\section{Conclusion}

The present study evaluated Q: Skills for Success textbooks for first year students depending on EFL instructors' perspectives at Taibah University. Instructors agreed on appropriateness and suitability of newly adopted textbooks in terms of objectives, contents, methods and techniques and ways of evaluation. The findings of the study showed that EFL instructors had some comments concerning the appropriateness of content and pictures to the local culture of the students as well to the absence of instructors' participation in the selection of objectives. The researcher suggested other researchers who are interested in Q: Skills for Success textbooks to conduct similar studies in other regions to find out if there are cultural differences concerning teaching Q: Skills for Success textbooks.

\section{Recommendations}

This study showed that EFL instructors had some negative comments related to the appropriateness of content and pictures to the Saudi culture. They also looked to the absence of instructors' participation in the selection of objectives as a weak point in these textbooks. Therefore it is recommended that EFL Instructors should participate in training activities, workshops, collaborative planning and classroom observation with a peer.

EFL instructors' perspectives are very important in the process of learning and teaching. Some classroom practices are based on these perspectives. However, their perspectives are very complicated so there should be further study into the same topic. Additionally, a similar study should be conducted with other universities in the Kingdom of Saudi Arabia to discover more about instructors' opinions about Q: Skills for Success textbooks. In addition, other studies concerning students' perspectives about the suitability of Q: Skills for Success textbooks should be conducted to improve these textbooks and make them more realistic and attractive. 


\section{References}

Abu Naba'h, M., Abu Samak, T., \& Massoud, A.(2016). Saudi EFL Teachers' Perceptions of the Intermediate Stage Textbooks. Dirasat, Educational Sciences, Supplement 43(2), 1103-1115. https://doi.org/10.12816/0033622

Ahmad, H., \& Shah, S. (2014). EFL Textbooks: Exploring The Suitability Of Textbook Contents From EFL Teachers' Perspective. VFAST Transactions on Education and Social Sciences, 5(1), 10-18.

Al Harbi A. (2017). Evaluation Study for Secondary Stage EFL Textbook: EFL Teachers' Perspectives. English Language Teaching, 10(3), 26-39. https://doi.org/10.5539/elt.v10n3p26

Al-Barakat, A., Bataineh, R., Al-Karasneh, S., \& Bataineh, R. (2006). Jordanian EFL teachers' perceptions of the pedagogical value of action pack textbook. ITL International Journal of Applied Linguistics, 151, 33-56. https://doi.org/10.2143/ITL.151.0.2015221

Aldera, S. (2017) Teaching EFL in Saudi Arabian Context: Textbooks and Culture. Journal of Language Teaching and Research, 8(2), 221-228. https://doi.org/10.17507/j1tr.0802.03

Alshehri, A. (2016). Textbook Evaluation: Teachers' Perspectives on Cutting Edge. International Journal of English Language Education, 4(2), 91-106. https://doi.org/10.5296/ijele.v4i2.9743

An Evaluation of EFL Materials Taught at Saudi Universities: Instructors' Perspectives. J. King Saud Univ., 26, Lang. \& Transl. (Special Issue), 1-15.

Banks, A., \& Ambrose, C. (1977). Teaching strategies for the social studies: Inquiry, Valuing, and Decision Making (pp. 489-490). Massachusetts: Addison: Wesley Publishing Company.

Cunningsworth, A. (1995). Choosing your coursebook. Macmillan: Heinemann

Ellis, R. (1997). The empirical evaluation of language teaching materials. ELT Journal, 51(1), 36-41. https://doi.org/10.1093/elt/51.1.36

Grant, N. (1987). Making the most of your textbook. London: Longman

Hutchinson, T., \& Torres, E. (1994). The textbook as agent of change. ELT Journal 48(4), 315-28. https://doi.org/10.1093/elt/48.4.315

McGrath, I. (2002). Materials Evaluation and Design for Language Teaching. Edinburgh: Edinburgh University Press.

Mohd-Ashraf, R. (2005). English and Islam: A clash of civilizations? Journal of Language, Identity \& Education, 4(2), 103-118. https://doi.org/10.1207/s15327701jlie0402_3

Moirano, C. (2012). Teaching the Students and not the Book: Addressing the Problem of Culture Teaching in EFL in Argentina. GIST Education and Research Journal, 6, 71-96.

Nevo, D. (1977). A Modal for Utilization of Formative Evaluation in the Process of Developing Instructional Materials. PLETA Journal, 14(2), 127-130. 
https://doi.org/10.1080/1355800770140205

Rea-Dickens P. P., \& Germaine, K. (1994). Evaluation In Canadlin and Widdowson (ed.), Oxford University Press.

Ta'amneh, M. (2005). EFL supervisors' and teachers' evaluation of action pack textbooks for beginning students in Jordan. Unpublished Master's Thesis, The Hashemite University, Zarka, Jordan.

Ta'amneh, M. (2014). Investigating Vocabulary Learning Strategies used by Pre-Service Teachers at Taibah University in learning English Vocabulary Items. International Interdisciplinary Journal of Education, 3(3), 143-148. https://doi.org/10.12816/0006862

Ta'amneh, M. (2015). Exploring the Harmony between Jordanian EFL Teachers' and Students' Beliefs about Vocabulary Learning Strategies. Journal of Language Teaching and Research (JLTR), 6(1), 78-84. https://doi.org/10.17507/jltr.0601.09

Worthen, B., \& Sanders, J. (1987). Educational Evaluation. New York: Longman.

\section{Copyright Disclaimer}

Copyright for this article is retained by the author(s), with first publication rights granted to the journal.

This is an open-access article distributed under the terms and conditions of the Creative Commons Attribution license (http://creativecommons.org/licenses/by/4.0/). 